\title{
In situ localization of mRNA of resembling the dirigent protein in sugarcane stems
}

\author{
Paula Nobile ${ }^{1 *}$, Juliana Mayer ${ }^{2}$, Michael Brito ${ }^{1}$, Izadora Pastore ${ }^{3}$, Pedro Araújo $^{1}$, Alexandra Bottcher ${ }^{1}$, Silvana Creste $^{3}$, \\ Paulo Mazzafera ${ }^{1}$ \\ From 5th Congress of the Brazilian Biotechnology Society (SBBIOTEC) \\ Florianópolis, Brazil. 10-14 November 2013
}

\section{Background}

The dirigent proteins (DP) families and resembling the DP (DP-like) are exclusive in land plants and related to plants defense and forming phenylpropanoids compounds optically active, mainly pinoresinol [1]. Pinoresinol is converted into a variety of lignans. The dirigent protein involvement is not confirmed in lignin formation, a biopolymer which is a negative factor for the ethanol cellulosic production. However, recently it was demonstrated Arabidopsis DP-like, AtDIR10, localization in the lignin polymerization site and a determinant role in the formation of a lignin specific root structure, named as Casparian strip [2]. Despite of the controversy of the DP forming-lignin its substrate diversity is consistent. Since DPs and DPs-like are represented by numerous members of gene families with high diversified sequences and with unknown functional role for most of them [3]. One of the sugarcane DP-like, named as ShDP1-like, showed special interesting due its high level of expression in the pith of mature stem [3] coinciding with higher level of the sinapyl (S) unit forming lignin [4]. Localization of DP expression to particular cell and tissue types is a necessary prerequisite in understanding the biological role of this gene.

\section{Methods}

In situ hybridization of mRNA

To examine the localization of ShDP1-like mRNA, the $191 \mathrm{pb}$ PCR product obtained from the stem cDNA of IACSP04-063 sugarcane variety using the ShDP1-like specific pair primers was cloning at pGEM easy vector (Promega). The linearized constructed vector was used for synthesis of digoxigenin-labeled antisense and sense

'Departamento de Biologia Vegetal, Instituto de Biologia, CP 6109,

Universidade Estadual de Campinas, Campinas, SP, Brazil

Full list of author information is available at the end of the article
RNA probes with the DIG RNA Labeling Kit (SP6/T7) (Roche). 20- $\mu \mathrm{m}$ sections of paraformaldehyde-embedded sugarcane stem were subjected to in situ hybridization as previously described [5]. Photomicrographs were captured with an Olympus BX 51 photomicroscope equipped with an Olympus DP71.

\section{Results and conclusions}

The ShDP1-like hybridization signals were detected in the vascular bundles and the fibers surround the vascular bundles in the young internode rind of the sugarcane stem, coinciding with the lignin accumulation. On the other hand, the stronger signals were detected in the parenchyma cells of mature internode pith and less pronounced signal in the vascular bundles and fibers of pith and rind cells. Interesting, unlike the parenchyma cells of young internode, the lignin accumulation appears in parenchyma cells of mature pith, and probably with a $\mathrm{S}$ unit-rich formation (4). Moreover, it is noteworthy that the sucrose accumulation also occurs on the parenchyma cells of mature pith. The results suggest a direct or indirect relation between ShDP1-like expression pattern and lignin accumulation. In order to access the ShDP1-like biological role, its coding sequence was isolated and cloned in overexpression vector. Currently, the transformed rice calli carrying the ShDP1-like overexpression cassette are regenerating.

\section{Acknowledgements \\ FAPESP sponsors post-doctorate fellowships to PMN, MSB, JLSM. FAPESP project Grant 2010/08232-0 and 2008/58035-6.}

\section{Authors' details}

'Departamento de Biologia Vegetal, Instituto de Biologia, CP 6109, Universidade Estadual de Campinas, Campinas, SP, Brazil. '2Departamento de Biologia, Universidade Estadual do Centro-Oeste, Guarapuava, PR, Brazil. ${ }^{3}$ Centro de Cana - Instituto Agronômico de Campinas, C.P. 206 - CEP: 14001970 - Ribeirão Preto, SP, Brazil. 


\section{References}

1. Davin LB, Wang H-B, Crowell AL, Bedgar DL, Martin DM, Sarkanen S,

Lewis NG: Stereoselective bimolecular phenoxy radical coupling by an auxiliary (dirigent) protein without an active center. Science 1997, 275:362-366.

2. Hosmani PS, Kamiya T, Danku J, Naseer S, Geldner N, Guerinot ML, Salt DE: Dirigent domain-containing protein is part of the machinery required for formation of the lignin-based Casparian strip in the root. ProcNat Acad Sci of USA 2013, 110:14498-14503.

3. Nobile PM, Creste S, Brito MS, Bottcher A, Santos AB, Moura JCMS, Anjos IA, Landell MGA, Vicentini R, Mazzafera P: The dirigent protein: to be or not to be lignin related? Sugarcane as a study case. Plant \& Animal Genome XX San Diego, CA.;https://pag.confex.com/pag/xx/webprogram/Paper2817. html], January, 14-18, 2012

4. Bottcher A, Cesarino I, Santos AB, Vicentini R, Mayer ULS, Vanholme R, Morree K, Goemine G, Moura JCMS, Nobile PM, Carmello-Guerreiro SM, Creste S, Anjos IA dos, Boerjan W, Landell MGA, Mazzafera P: Lignin in sugarcane: biochemical and gene expression characterization of two cultivars contrasting for lignin content. Plant Physiology Submetted in 19th July 2013.

5. Cesarino I, Araújo P, Mayer JLS, Vicentini R, Berthet S, Demedts B, Vanholme B, Boerjan W, Mazzafera P: Expression of SofLAC, a new laccase in sugarcane, restores lignin content but not $\mathrm{S}: \mathrm{G}$ ratio of Arabidopsis lac17 mutant. J Exp Bot 2013, 64:1769-1781.

doi:10.1186/1753-6561-8-S4-P119

Cite this article as: Nobile et al:: In situ localization of mRNA of resembling the dirigent protein in sugarcane stems. BMC Proceedings 2014 8(Suppl 4):P119.

\section{Submit your next manuscript to BioMed Central and take full advantage of:}

- Convenient online submission

- Thorough peer review

- No space constraints or color figure charges

- Immediate publication on acceptance

- Inclusion in PubMed, CAS, Scopus and Google Scholar

- Research which is freely available for redistribution

Submit your manuscript at www.biomedcentral com/submit 